\title{
A GENDERED CRITIQUE OF THE CATHOLIC CHURCH'S TEACHING ON MARRIAGE AND THE FAMILY: 1965-2016
}

\author{
Susan Rakoczy \\ School of Religion, Philosophy and Classics \\ University of KwaZulu-Natal
}

\begin{abstract}
The teachings of the Roman Catholic Church on marriage and the family have been developed with very little consultation with women for whom these teachings have great importance. This article focuses on these teachings from the close of the Second Vatican II in 1965 to 2015 and the Synod session on marriage and the family. It briefly discusses the Church's understanding of marriage from the Patristic era to the Council of Trent and then analyses the development of the theology of marriage in Vatican II, Humanae Vitae, the 1968 encyclical on contraception, Pope John Paul II's theology of marriage and the Synod sessions called by Pope Francis in 2014 and 2015, including his Apostolic Exhortation Amoris Laetitia issued in 2016. Where are the voices of women, especially African women, in shaping Catholic theology of marriage?
\end{abstract}

Key Words: Family; Gender; Humanae Vitae; Marriage; Pope Francis;

Pope John Paul II; Vatican II; Women

\section{Introduction}

The teachings of the Catholic Church on marriage and the family were highlighted in the world's media during the Synod sessions in Rome in 2014 and 2015. Pope Francis asked the bishops to speak openly about the many issues pertaining to these core human experiences and they did. This article analyses the teachings of the Catholic Church on marriage and the family since the Second Vatican Council (1962-1965) with a special focus on gender. How does the multi-faceted teaching, written by bishops and popes with very little explicit input from women, speak to $21^{\text {st }}$ century Catholics? What does Pope Francis's Apostolic Exhortation Amoris Laetitia contribute to Catholic teaching on marriage?

\section{Roman Catholic Perspectives on Marriage before Vatican II}

From the beginning of Christian life, Christians married according to the culture of their times, Jewish and Greco-Roman. ${ }^{1}$ There were no specific church ceremonies. Bernard Cooke comments that the first generation of Christians "would have regarded marriage as an arrangement between two people who wished to share life and establish their own household... (and) would not have regarded their marriage as anything distinctively related

See Margaret A Farley, Just Love: A Framework for Christian Sexual Ethics, New York and London: Continuum, 2006:247-259; Francis Schüssler Fiorenza, Marriage, in Francis Schüssler Fiorenza and John P Galvin (eds.), Systematic Theology: Roman Catholic Perspectives, Volume II, Minneapolis: Fortress Press, 1991:317-324; Theodore Mackin, What is Marriage?, New York: Paulist Press, 1982:69-127, 145-175. 
to their Christian faith." ${ }^{2}$ They would have understood that the marital union was to mirror the union of Christ and the Church (Eph. 5:28-33).

Patristic teaching on marriage was heavily influenced by a negative interpretation of sexuality. The views of Augustine of Hippo (354-430) were very influential. He taught that "sexual expression is never without grave sin outside marriage; even within marriage it is always touched by venial sin unless the couple desire only the generation of a child and do not directly seek the pleasure attached to intercourse."3 The procreation and education of children was thus "the first and dominant 'good' that Christians should seek in their marriage." 4 This became the basic principle of Catholic teaching on marriage until the $20^{\text {th }}$ century.

In 1184 the Council of Verona made the first declaration that marriage is a sacrament; this was included in the condemnation of the Cathars, a heterodox group. ${ }^{5}$ Dualism was the foundation of the Cathar world view: spirit was good, matter was evil. Thus sexuality and marriage were evil and Cathars were to be celibate. Although the Church was suspicious of sexuality, the naming of marriage as a sacrament in opposition to the Cathars was a very important development in the theology of marriage.

The Protestant Reformation in the $16^{\text {th }}$ century included a married clergy in the Western church, a practice which had been kept in the East but had not been seen in the West for many centuries. In reference to clerical celibacy, Margaret Farley comments that "Marriage and family replaced it among the reformers as the centre of sexual gravity in the Christian life". 6 The Council of Trent (1545-1563) "was the first ecumenical council to address the role of love in marriage, but it also reaffirmed the primacy of procreation and reemphasised the superiority of celibacy."7 However, monastic and religious vows continued to be seen as of greater value than marriage vows.

Down the centuries the "generation of children has assumed almost unchallenged primacy as the goal of marriage" ${ }^{, 8}$ with the relationship between the spouses of secondary importance until Vatican II. This perspective heavily influenced the issue of contraception which became important in the $20^{\text {th }}$ century.

The Anglican Lambeth Conference in 1930 gave approval for artificial contraception in marriage. Somewhat in reply, Pope Pius XI issued the encyclical Casti Connubi also in 1930 which reaffirmed the procreative focus on marriage. It was issued in a context of "higher divorce rates, the movement for women's suffrage and an increasingly secularised view of society." He both affirmed the tradition - the ranking of the ends of marriage as first for procreation and secondly for mutual help and as a remedy for concupiscence (the latter was Augustine's view) ${ }^{10}$ and went further by describing marriage as "a complete and intimate life-partnership and association" $(C C 24) .{ }^{11} \mathrm{He}$ also stated that "it was morally licit

Bernard Cooke, "Historical Reflections on the Meaning of Marriage," in Charles E Curran and Julie Hanlon Rubio (eds.), Marriage. New York: Paulist Press, 2009:11.

Cooke, 19.

Cooke, 19.

Schüssler Fiorenza, "Marriage," 320.

Farley, Just Love, 45.

Farley, 47.

Cooke, 14.

Susan A Ross, "The Bride of Christ and the Body Politic: Body and Gender in Pre-Vatican II Moral Theology," in Charles E Curran and Julie Hanlon Rubio (eds.), Marriage. New York: Paulist Press, 2009:37.

10 De Bono Conjugali, 16, 18, PL 40, 385; cf. Contra Faustum 22, 30, PL 42, 438, cf. fn. 4, Joseph A Selling, "Regulating Fertility and Clarifying Moral Language". The Heythrop Journal 55, 2014:1042.

11 Pope Pius XI, Casti Connubi. London: Catholic Truth Society, 1957. 
for a married couple to engage in sexual intercourse known beforehand to be infertile, a position already held by many, but not certainly not all, moral theologians at the time."12

In his address to the Italian Society of Catholic Midwives in 1951, Pope Pius XII gave approval to the 'rhythm method' which is based on avoiding sexual intercourse during the fertile periods of a woman's menstrual cycle and said that "this method could be used even on a permanent basis when serious medical, economic, or social reasons obtained."13

On the eve of Vatican II in 1962, Catholic teaching on marriage was based on the primacy of the procreation of children, a long-standing suspicion of sexual pleasure, and the relationship between the spouses as of secondary importance.

\section{Vatican II: Marriage and the Family in Gaudium et Spes}

The Pastoral Constitution on the Church in the Modern World (Gaudium et Spes 1965) was a creative and far-ranging document in which the bishops of Vatican II addressed crucial problems of their time, including marriage.

Setting aside centuries of fear, distrust and judgement of 'the world', the Council declares its solidarity with humanity:

The joy and hope, the grief and anguish of the men of our time, especially those who are poor or afflicted in any way, are the joy and hope, the grief and anguish of the followers or Christ as well. Nothing that is genuinely human fails to find an echo in their hearts $(G S 1) .^{14}$

The Church "travels the same journey as all mankind and shares the same earthly lot with the world: it is to be a leaven and, as it were, the soul of humanity its renewal by Christ" (GS 40).

The first draft of a document on marriage which had been prepared by the chair of the Council's theological commission, Cardinal Alfredo Ottaviani, was extremely negative and condemned abuses of marriage that it judged "to be the most widespread and grievous, with divorce and contraceptive intercourse principal among them." contract between two persons and had a very juridical approach to the sacrament. The bishops totally rejected this draft and wrote a creative interpretation of marriage "even to the extent of putting in abeyance Catholic doctrine that had been taught for centuries." 16 This was the traditional teaching that the primary end of marriage was the procreation of children.

Theodore Mackin, a Jesuit theologian of the theology of marriage, calls attention to the context of the bishops' concerns which included: “...the fragility of family life and of marital love under the duress of economic and political forces that attack stable society at every point." 17 In the 1960s these "economic and political forces" included the Cold War, with the threat of nuclear war evident, especially in the Cuban Missile Crisis in October, 1962, soon after the Council opened. African countries were gaining their independence from colonial powers. In South Africa apartheid tightened its stranglehold after the 
Sharpeville Massacre in 1960. The bishops wished to address their reflections on marriage "not only to Christians but to all persons concerned about the well-being of marriage.", 18 This was a new perspective in Catholic teaching, demonstrating the bishops' concern for those outside the Catholic Church.

\section{Drafts of the Chapter on Marriage}

The debates on the section on marriage in the 1964 session "concentrated on the Church's teaching on marriage in general and on two issues in particular: the ends or purposes of marriage and birth control."19 The bishops who spoke were both conservatives - the draft did not restate traditional teaching strongly enough - and liberals, those who wanted a more contemporary teaching for the modern world. For instance, Cardinal Ottaviani said that the draft "placed too much emphasis on the choice of spouses deciding the number of their children." 20 Another bishop said that the text did not sufficiently emphasise "supernatural faith, confidence in divine providence, love and acceptance of the cross." ${ }^{21}$ Such a statement spiritualises marriage in ways that are not helpful to married people.

Cardinal Leon-Joseph Suenens of Belgium, a leading liberal Council father, asked whether "the communion of the spouses should not be given equal status with procreation as an end of marriage." 22 An Indonesian bishop called for the inclusion of laity in the commission drafting this document since they "represent married people better than bishops and priests can."23

African and Asian voices were also present. Bishop Joseph Ngogi Nkongolo from the Congo stressed the necessity of free consent in marriage and the evils of polygamy which "gravely damages the personal dignity of women". ${ }^{24}$ A bishop from Indonesia, speaking on behalf of twenty-nine bishops from Asia, criticised this draft as too Western. He quoted a Pakistani woman: "You contract marriage because you love, we love because we are joined in matrimony." 25 He argued against giving primacy to love since "outside the West marriage is often settled by the couple's parents and mutual love grows gradually as the fruit of marriage." 26

There was much discussion about the 'ends' of marriage: how were procreation and mutual love to be articulated in this emerging theology of marriage? Bishop Remi DeRoo had consulted many married couples and so emphasised the riches of conjugal love. Other bishops wanted the document to anticipate everything and condemn everything: divorce, adultery, abortion and sterilisation.

Although Pope Paul VI had already removed contraception from the Council's agenda and appointed a commission to study the issue, it was often mentioned. One of the ecumenical observers criticised the debate in which "two thousand celibates have debated the morality of birth control." 27

\footnotetext{
Mackin, 59.

19 Giuseppe Alberigo (ed.) and Joseph Komonchak (English version editor), History of Vatican II, Volume 4, translated by Matthew J O'Connell. Leuven: Peeters/Orbis, 2006:307.

Alberigio, History, Volume 4, 308.

Alberigo 4:309.

Alberigo 4:310.

Alberigo 4:311.

Alberigo 4:312.

Alberigo 4:381.

Alberigo 4:381

Alberigo 4:312.
} 
One bishop feared that the teaching would "justify propaganda in favour of birth control in Africa, Asia and Latin America." 28 The Patriarch Elias Zoghby of the Melkite Church in Egypt expressed pastoral concern for "the innocent spouse who in the prime of life and without any fault is left alone by the sin of the other." ${ }^{29}$ He suggested that the Church look to the practice of the Oriental Churches separated from Rome, which while maintaining the indissolubility of marriage, allow an innocent partner to remarry. His remarks received much publicity and the next day Cardinal Charles Journet strongly re-emphasised the indissolubility of sacramental marriage.

There was a strong tension in the Council debates between discussing "marriage and family as if these were mental constructs, while others looked upon them as historical realities." "30 The central question was how was the Church to be "in the modern world"? Were the signs of the times, such as industrialisation and urbanisation, seen as threats to the family? Bishop Herbert Bednorz, representing the Polish bishops, had asked "was work undertaken by women simply a danger that might lead to their emancipation?",31

What then, did the bishops decide to say in Gaudium et Spes?

\section{Gaudium et Spes on Marriage}

In Section 47 the context of twentieth century married life is described: "polygamy, the plague of divorce, so-called free love ... and married love is too often dishonoured by selfishness, hedonism, and unlawful contraceptive practices" (GS 47). Economic, social and psychological factors also impact marriage and family life.

The 1917 Code of Canon Law, operative during Vatican II, described marriage as a 'contract'. Canon 1012 stated: "Christ our Lord elevated the very contract of marriage between two baptised persons to the dignity of a sacrament." 32 True, but as seen above, the Church did not use the language of sacrament in reference to marriage until the $12^{\text {th }}$ century. The first significant shift in the Council's teaching on marriage was to use the language of personalism: marriage is a 'partnership of love' $(G S 47)$ and marital love is "an eminently human love because it is an affection between two persons rooted in the will and it embraces the good of the whole person" (GS 49). Marriage is a covenant, not a contract, between the partners. It is a sacrament and thus "its source is God's love for the spouses". 33 It is a sacrament which the spouses confer to one another through their vows.

The traditional theology of marriage had posited the procreation and education of children as the end of marriage. Mutual love and support were second. Gaudium et Spes makes these equal and states that "the intimate union of marriage, as the mutual giving of two persons, and the good of the children demand total fidelity from the spouses and require an unbreakable unity between them" (GS 48).

Mackin comments that the bishops deliver "a formal rebuff to eighteen centuries of Christian fear and suspicion of sexuality" 34 with their positive statements about marital sexuality: "Hence the acts in marriage by which the intimate and chaste union of the

Alberigo Giuseppe Alberigo (ed.) and Joseph Komonchak (English version editor), History of Vatican II, Volume 5, translated by Matthew J O’Connell. Leuven: Peeters/Orbis, 2006:157.

29 Alberigo History of Vatican II, Volume 5:158.

30 Alberigo 5:161.

31 Alberigo 5:162.

32 Bouscaren, T Lincoln and Ellis, Adam C, Canon Law: A Text and Commentary. Milwaukee: The Bruce Publishing Company, 1946:397.

33 Mackin, "The Second Vatican Council," 60.

34 Mackin, 62-63. 
spouses are noble and honourable" (GS 49). Influenced by Augustine, the church had taught that marriage was a remedy for controlling sexuality. ${ }^{35}$ But the bishops say something different: marital love is primarily fertile and creative, both in the love of the partners for each other and for their children (GS 49).

"Married couples should regard it as their proper mission to transmit human life and to educate their children" (GS 50), which is a cooperation with the love of God. The bishops recognised that married people "sometimes find themselves in a position where the number of children cannot be increased, at least for the time being" (GS 51). The couple is to consider "their own good and the good of their children already born or yet to come ... and of their own situation on the material and spiritual level" (GS 50) in terms of how many children to have. But large families are also commended (GS 50). At the same time, marriages without children are a "communion of life" (GS 50).

The dynamics of the marital union are personal and indissoluble and "the good of the children demand that the mutual love of the partners be properly shown, that it should grow and mature" (GS 50). The bishops affirmed the important role the father has in the upbringing of the children and while affirming the importance of the mother's presence with the children, also did not wish to underrate "women's legitimate social advancement" (GS 52).

Life must be protected from the moment of conception and thus abortion and infanticide are 'abominable crimes' (GS 51). In terms of "birth regulation, the sons (sic) of the Church...are forbidden to use methods disapproved of by the teaching authority of the Church in its interpretation of the divine law" (GS 51). This contentious issue had been taken from the Council's agenda and given to a special commission.

\section{Lay Influence on Gaudium Spes and Marriage}

There is much to commend in this personalist theology of marriage. But although it was written by celibate men, the views of laity influenced them. There were official male ${ }^{36}$ and 23 female auditors, plus ecumenical observers. Some of the bishops who spoke during the debate indicated that they had consulted married couples. The president of the commission which was working on the section on marriage invited the one married couple at the Council who were auditors, Luz-Marie and José Icaza of Mexico, to share their experience as members of the Christian Family Movement and give their views on the marriage section in the draft document. "The Icazas told them that what was written about the Christian family was poorly done. After that the sub-commission began to listen to them." 37

They were invited to a plenary session of the Mixed Commission which was discussing the marriage section. After hearing the very conservative views of some cardinals, LuzMarie thought her husband should speak up but he insisted she do so. She asked the bishops why they were putting so much emphasis on concupiscence and sin in marriage and then told them: 
Since I am the only married woman here, I feel I have the responsibility of saying that when we have had intercourse, giving life to our children, it wasn't an act of concupiscence $^{38}$, but an act of love, and I believe that this is true of most Christian mothers who conceive a child. With all respect, I tell you that when your mothers conceived you, it also was in love. ${ }^{39}$

Another auditor, Pilar Bellosillo of Spain, was also able to assist the bishops in drafting the section on marriage. A single woman, she had been president of an important women's organisation, WUWCO (World Union of Catholic Women's Organisations), and knew the challenges that women faced in their marriages and raising their families. She made the link between women's dignity and marital sexuality: “Once human dignity is seen as referring equally to woman and man, the traditional doctrines have to change because it is against woman's dignity to be considered only as a functionary of man, especially from the sexual point of view." ${ }^{40}$ It was obvious that the bishops needed help in drafting the marriage section and so the auditors formed a sub-commission, led by the Icazas, who communicated with the relevant commissions.

So we can say that the views of the laity, including women, did help to shape the theology of marriage which Gaudium et Spes developed. McEnroy comments on the role that the Icazas played: "...their names deserve to be spoken and preserved wherever and whenever the document is read or invoked." 41

\section{Contraception and Humanae Vitae}

The commission that drafted the marriage section of Gaudium et Spes was very aware that "there should be no formulations that would give the impression that the question of birth limitation was already decided."42 Pope Paul VI had taken this issue off the Council's agenda and reserved action to himself. On 23 June 1964, between the second and third sessions of the Council, he expanded the Pontifical Study Commission on Population Control which John XXIII had established. Among the seventy-five members of the commission were Patrick and Patricia Crowley, an American couple and also leaders in the Christian Family Movement (CFM). They had consulted their members and had received thousands of letters describing their experiences with the rhythm method, which had often failed them. When the Commission began its work there were "three numerically equal groups, representing different positions: natural family planning, the pill and acceptance of the pill under certain conditions." 43 The Commission issued its report in 1966 and recommended "a change toward mitigation of the proscription of artificial birth control."44 Selling notes that "when the commission submitted its report to Paul VI in 1966, it advised that the teaching on contraception should be allowed to evolve and that simply condemning individual acts as 'intrinsically evil' did not properly respond to the vision of marriage and sexuality promulgated by the council. For it was not the individual act that should be considered to be fruitful but the entirety of married life." 45

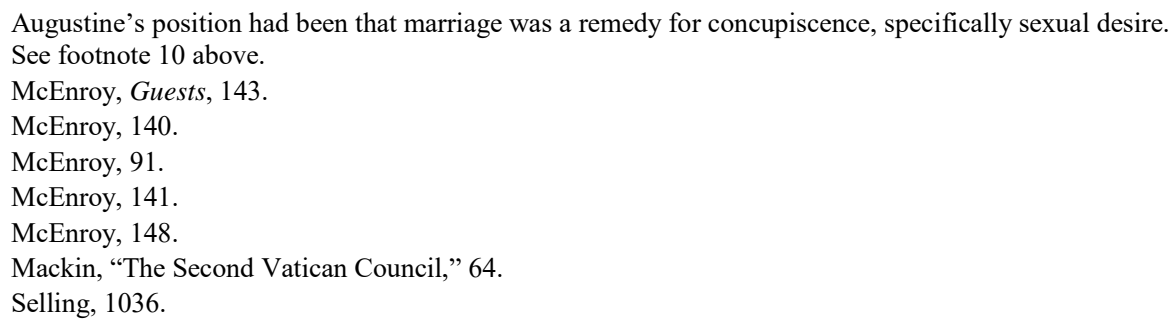


At first Paul VI "had come around to accepting the majority position" 46 but then Cardinal Ottaviani told him that if the teaching on contraception was changed, the Church would lose its moral authority. Bernard Häring CSsR, a prominent moral theologian, tried to see the Pope but "neither he nor anyone else from the majority position ever gained access to Paul VI." 47 Mackin stated that before Paul VI wrote Humanae Vitae he "had already made up his mind to not contract the proscriptive judgment his predecessors had passed on artificial conception." 48

What did Humanae Vitae say? Section \#2 describes the context of addressing the problem: rapid population increase and the fears surrounding it "with the consequence that many families and developing countries are being faced with greater hardships" (HV 2). ${ }^{49}$ It also draws attention to the position of women: "It is also apparent that, with the new understanding of the dignity of woman, and her place in society, there has been an appreciation of the value of love in marriage and of the meaning of intimate married life in the light of that love" ( $H V 2)$.

The Pope describes marital love as fully human, total, faithful and exclusive, and creative of life ( $H V 9)$. He has decided to examine the question of birth control:

...because, if for no other reason, there was lacking complete agreement within the

Commission itself as to what moral norms to put forward. This was all the more

necessary because certain approaches and criteria for a solution which were at variance

with the moral doctrine on marriage constantly taught by the Magisterium of the Church

(HV 6).

Paul VI was very wary of any change in Church teaching on contraception.

Marital love includes awareness by husband and wife of the obligations of responsible parenthood which includes biological, physical, economic, psychological and economic factors. It is also related to "the objective moral order instituted by God" ( $H V 10)$. This means that they "are not free to do as they like in the service of transmitting life, as if it were wholly up to them to decide what is the right course to follow" (HV 10).

The core teaching of Humanae Vitae is framed within natural law: "The Church, nevertheless, in urging men to the observance of the precepts of natural law, which it interprets by its constant doctrine, teaches as absolutely required that in any use whatever of marriage (sic) there must be no impairment of its natural capacity to procreate human life" $(H V 11)$. Abortion and direct sterilisation are forbidden. In addition, "Similarly excluded is any action, which either before, at the moment of, or after sexual intercourse, isspecifically intended to prevent procreation - whether as an end or as a means" ( $H V$ 14). This is premised on the inseparability of the unitive and procreative meanings of marriage. ${ }^{50}$

The Pope does affirm that if "there are reasonable grounds for spacing births ... married people may take advantage of the natural cycles immanent in the reproductive system and use their marriage at precisely those times that are infertile" ( $H V 16)$. Married couples are thus responsible for discerning the number of children they would like to have since many factors impinge on raising children, including economic factors. Today these methods based on a woman's menstrual cycle are described as Natural Family Planning. He says that the Church "condemns as always unlawful the use of means which directly exclude

\footnotetext{
McEnroy, 148.

McEnroy, 148.

Mackin, 275.

Pope PauP1 VI, Humanae Vitae (“On Human Life”). London: Catholic Truth Society, 1970.

See Mackin, 276-277.
} 
conception, even when the reasons given for the latter are neither trivial nor immoral" ( $H V$ 16).

One of the reasons for the condemnation of these forms of birth control was the Pope's fear of "marital infidelity and a general lowering of moral standards" ( $H V 17)$. He was also alarmed that the use of these methods would lead men to "forget the reverence due a woman, and, reduce her to being a mere instrument for the satisfaction of his own desires" (HV 17).

The Pope anticipated the opposition that was to come from this teaching but asserted that the Church is "only the guardian and interpreter of these laws" ( $H V 18)$.

\section{Critique of the Teaching}

Selling points out that the statement that "This particular doctrine, often expounded by the Magisterium of the Church, is based on the inseparable connection, established by God, which man on his own initiative may not break, between the unitive significance and the procreative significance which are both inherent to the marriage act" ( $\left.H V{ }^{13}\right)$ has no 'precedent' and "it is nowhere to be found in the moral tradition of the church". ${ }^{51}$ He argues that "Paul VI had introduced a new teaching in order to substantiate a position that he was resolute to uphold, namely that nothing outside of sexual intercourse may be used to regulate fertility." 52

He also states that "It has become increasingly evident that the real mind behind the encyclical was, in fact, Karol Wojtyla, later to become Pope John Paul II. The principle ideas upon which HV is built can now be traced to this source." 53

Michael J Barberi and Joseph A Selling argue that Wojtyla's influence on Humanae Vitae is clear. ${ }^{54}$ After the Papal Birth Control Commission issued its report in 1966, he established the Krakow Commission to study the majority and minority reports of the Commission. Humanae Vitae's 'inseparability principle' of the unitive and procreative dimensions of sexual intercourse is found both in the work of the Krakow Commission and Wojtyla's Love and Responsibility. ${ }^{55}$

Selling also points out that the use of the term 'intrinsically evil' ( $H V$ 14) is also problematic. ${ }^{56}$ People term murder an 'evil' act but preventing conception is termed intrinsically evil. This language is used "to pass judgement upon a material act without taking into account either the persons who might perform such an act or the circumstances within which they find themselves." 57 Humane Vitae also creates the impression that the Church has had a long, single, unchanging teaching on contraception throughout its history. That is Commission and Love and Responsibility, 374-378

56 See also the interpretation of "intrinsically evil acts" by Pope John Paul II in his 1993 encyclical Veritatis Splendor ("The Splendor of Truth") in which he lists a number of such acts such as homicide, genocide, abortion, euthanasia - and contraception (\#80). In Evangelium Vitae (1995) he speaks of the "culture of death" which includes abortion and contraception (\#12).

Selling, 1037.

Selling, 1037.

Selling, fn. 10, 1042. Cardinal Woytyla was a member of the Papal Birth Control Commission but was unable to attend meetings because the Polish government would not grant him a visa.

See Michael J Barberi and Joseph A Selling, "The Origin of Humanae Vitae and the Impasse in Fundamental Theological Ethics,” Louvain Studies 37, 201:364-389.

Selling, 1041. 
not true, as the evolution in the twentieth century makes clear. ${ }^{58}$ The Natural Family Planning methods of today "would have been unanimously rejected by Catholic moral theologians" 59 a hundred years ago.

\section{Reception of the Teaching of Humane Vitae}

Many Catholics around the world were expecting a change in the Church's teaching on contraception. Thus Humane Vitae was a huge disappointment and theologians, some bishops and laity, especially in the West, responded first with shock and then with opposition. The German theologian Hans Küng declared: "Those who reach the conclusion, after mature deliberation with themselves, that to preserve their marital happiness they cannot be guided by the principles enunciated in this encyclical must follow their own consciences." ${ }^{\circ 0}$ An earlier section in Gaudium et Spes discussed conscience and stated: "For man has in his heart a law inscribed by God. His dignity lies in observing this law, and by it he will be judged" (GS 16).

A group of theologians in the United States "openly dissented from the teaching of Humanae Vitae" and "identified the grounds of their dissent in terms of the encyclical's ecclesiology and methodology." 61 To Charles Curran and others "the encyclical appears to favour a biological over a more integral understanding of the person, and conjugal acts over the totality of marriage." ${ }^{62}$ Bishops suspended priests for publicly disagreeing with the teaching; lay Catholics, especially women, were confused and often angry.

In South Africa, Archbishop Denis Hurley was extremely dismayed by the teaching of Humanae Vitae and the way Pope Paul VI had decided on it. He wrote, "But I would not be honest if I said that I agreed with the method of consultation - and with the result." ${ }^{\prime 63}$ The response of the Southern African Catholic Bishops' Conference "allowed some latitude for the exercise of conscience in relation to the use of contraception." ${ }^{\text {" T4 }}$ Two other prominent bishops supported the Pope. Cardinal Owen McCann of Cape Town said "that the Holy Father had spoken and he was the supreme teaching authority" and Archbishop John Garner of Pretoria agreed, saying "The surprising thing is that so many are surprised that the Holy Father should have reaffirmed the constant teaching of the Church on the subject., 65

Today, almost fifty years later, Christine Gudof, a moral theologian, asserts that the prohibition of any method of contraception other than Natural Family Planning is "taken seriously only by a small minority of Catholics, even among the clergy." ${ }^{66}$ However, clergy ordained during the pontificates of John Paul II and Benedict XVI often strenuously defend

See John T Noonan Jr's Contraception: A History of its Treatment by the Catholic Theologians and Canonists. Cambridge, Massachusetts: Harvard University Press, 1966.

59 Selling, 1042.

60 Quoted in Paddy Kearney, Guardian of the Light: Denis Hurley Renewing the Church, Opposing Apartheid. Pietermaritzburg: University of KwaZulu-Natal Press, 2009:135.

61 Darlene Fozard Weaver, "Vatican II and Moral Theology,” in Heft, James L (ed.) with O’Malley, John, After Vatican II: Trajectories and Hermeneutics. Grand Rapids, Michigan: William B Eerdmans Publishing Company, 2012:37-38.

62 Weaver, "Vatican II," 38.

63 Archbishop Denis Hurley, "I Don't Think I Have Ever Felt So Torn in Half." The Southern Cross, 7 August 1968, 1.

64 Kearney, Guardian of the Light, 158.

65 Kearney, 135.

${ }^{66}$ Christine Gudorf, "After Cairo: New Complexities in Fertility and Development."

The Heythrop Journal, 55 2014:1094. 
Humanae Vitae. Because the Church has focused for so long on condemning contraception (one of the litmus tests for becoming a bishop, along with opposition to abortion and women's ordination) it will be very difficult to change this position.

\section{John Paul II and Familiaris Consortio}

In October 1980 - fifteen years after the close of Vatican II and twelve years since Humane Vitae - a Synod of Bishops was held which focused on "The Duties of the Christian Family in Today's World". Pope John Paul II then wrote the Apostolic Exhortation Familiaris Consortio (1981) on the Synod's decisions, shaped by his own theology.

Much of the language reflects Vatican II. The sacramental character of marriage is stressed and thus "spouses are bound to one another in the most profoundly indissoluble manner" $(F C 13)^{67}$ which is understood as related to the covenant which God has with humanity. Sexuality is "by no means something purely biological, but concerns the innermost being of the human person as such" ( $F C$ 12). The total physical self-giving of marriage is "the sign and fruit of a total personal self-giving, in which the whole person is present" (FC 12).

Children are a "living reflection of their love, a permanent sign of conjugal unity and a living and inseparable synthesis of their being a father and mother" (FC 14). The family is a communion of persons "through which each human person is introduced into the "human family' and into the 'family of God', which is the Church" (FC 15). The Synod stressed four important tasks of the family: "forming a community of persons, serving life, participating in the development of society, and sharing in the life of the Church" (FC 17).

Several sections address the role of women. The Pope states that the "equal dignity and responsibility of women with men" $(F C 22)$ is a God-given dignity. This dignity is linked with that of Mary, who as the Mother of God, is "the model of redeemed women" (FC 22). Reflecting on the role of women in society, the Pope is of two minds. On the one hand he states that "There is no doubt that the equal dignity and responsibility of men and women fully justifies women's access to public functions" (FC 23). But on the other hand he asserts that the maternal and family role of women must be primary "in comparison with all other public roles and all other professions" (FC 23).

Here the Pope's "Polish context informs his argument that women should not be compelled by government or economic necessity to work outside the home."68 The Communist government dictated that all women had to work outside the home. When Communism ended they continued to work for economic reasons and like women around the world, juggled two jobs - taking care of their home and family and their work outside the home.

But John Paul projects the Polish experience on to women throughout the world and states that:

While it must be recognised that women have the same right as men to perform various public functions, society must be structured in such a way that wives and mothers are not in practice compelled (sic) to work outside the home, and that their families can live and prosper in a dignified way even when they themselves devote their full time to their own family ( FC 23). 
What will allow women to stay home and raise the children? The answer is to restructure society so that there is no economic necessity for women to work. The Pope states that "society should create and develop conditions favouring work in the home" through the introduction of a 'family wage' which is "a single salary given to the head of the family for that person's work or other measures such as family allowances or grants to mothers devoting themselves exclusively to their families" (FC 23). The Pope affirms the traditional role in the home: the head of the family is the father and the bread winner; the wife and mother stays home. There is no recognition that while some women work for low wages out of sheer necessity, other women work as doctors, lawyers, teachers, etc. not only to help the family bank account and contribute to society but also for their psychological and spiritual well-being.

The Synod speeches contained a number of interventions that "emphasised that the time had come to take women seriously in Church and society." 69 But John Paul II does not concur. His view is that a woman can work outside the home until the children are born and then she must stay home to raise them. This is a romantic and idealistic perspective which has little in common with the reality of life for women in 1980, or today.

However, Familiaris Consortio does condemn various forms of the degradation of women such as slavery, pornography, prostitution, and "forms of discrimination that exist in the fields of education, employment, wages, etc." (FC 24). These all exist because women are considered objects, not persons. Discrimination against women who are childless, widows, separated or divorced and unmarried mothers is deplored (FC 24).

In 1980 Catholics had had twelve years to ponder Humanae Vitae. At the Synod, Archbishop John Quinn of San Francisco spoke to the widespread rejection of the ban on contraception and stressed this opposition was "found even among those whose lives are otherwise outstanding in their Christian dedication and among theologians and pastors whose learning, faith, discretion and dedication to the Church are beyond doubt." ${ }^{70} \mathrm{He}$ cited a study in the United States which found that "76.5 percent of American Catholic women [...] were using some form of birth regulation and that 94 percent were using methods condemned by the encyclical." ${ }^{, 71} \mathrm{He}$ and Cardinal Basil Hume of Britain called for serious dialogue on this issue since the non-reception of the teaching was "a profound theological and pastoral problem". 72

But this was a minority position and the bishops were "particularly scathing in their rejection of surveys and sociological data." ${ }^{, 73}$ Cardinal Pericle Felici, President of the General Secretariat of the Synod, said that "the encyclical is closed." 74 Familiaris Consortio describes Humanae Vitae as "a truly prophetic proclamation ... regarding marriage and regarding the transmission of human life" ( $F C$ 30). Contraception is condemned because the partners do not give themselves to each other "in personal totality" (FC 31).

However, the Pope recognises that the "sense of the faithful", their living faith and reception of Church teaching, is significant and thus "Christian spouses and parents can and should offer their unique and irreplaceable contribution to the elaboration of an authentic evangelical discernment in the various situations and cultures in which men and women

Peter Hebblethwaite, Introducing John Paul II. London: Collins, 1982:123.

Julie Clague, "Catholics, Families and the Synod of Bishops: Views from the Pews," The Heythrop Journal 55, 2014:986 - see fn. 7 for the original references.

Clague, "Catholics, Families," 986, see fn. 8 for the original reference.

Clague, 986, see fn. 11 for the original reference.

Clague, 986.

Clague, 986, see fn. 14 for the original reference. 
live their marriage and their family life" (FC 5). But if the hierarchy listens to married people, it may hear things it does not wish to hear.

Recognising that the lay faithful are not accepting Humanae Vitae, the bishops and the pope called for "a new and stronger confirmation of the importance of the authentic teaching on birth control" (FC 31) of Vatican II and the encyclical. They call on theologians to work with the Magisterium to make clear "the biblical foundations, the ethical grounds and the personalistic reasons behind this doctrine" (FC 58). Advocates of the Pope John Paul II's "Theology of the Body" do this, but it is unclear how much influence they have on the people in the pews who do follow their conscience in reference to family planning.

\section{Pope Francis and the Synods on Marriage and the Family: 2014 and 2015}

Soon after his election as pope in March 2014, Pope Francis addressed the problems of marriage and the family in his Apostolic Exhortation Evangelii Gaudium ("The Joy of the Gospel", 2013). He calls attention to the crisis that marriage and the family are experiencing today. He views this as very serious because "the family is the fundamental cell of society, where we learn to live with one another and to belong to one another" $(E G 66){ }^{75}$ A symptom of this crisis is that "Marriage now tends to be viewed as a form of mere emotional satisfaction that can be constructed in any way or modified at will" (EG 66). He states that "The family is experiencing a profound cultural crisis, as are all communities and social bonds. In the case of the family, the weakening of these bonds is particularly serious because the family is the fundamental cell of society" (EA 66).

These concerns led him to call two sessions of the Synod of Bishops to discuss issues relating to marriage and the family. The first was the Extraordinary Synod on "The Pastoral Challenges of the Family in the Context of Evangelisation" held in Rome in October 2014. It was preceded by a consultation of Catholics around the world, coordinated by the national bishops' conferences, to learn what Catholics understood about the Church's teaching on marriage and the family. ${ }^{76}$ The German conferences released its findings which revealed that there was widespread disagreement on issues such as contraception and the reception of the Eucharist by persons who had divorced and remarried without an annulment. The Southern African Catholic Bishops' Conference did not release the views of Catholics in this country.

At the Synod, Pope Francis told the bishops to speak frankly and many did. There were some calling for changes in church discipline, such as Cardinal Reinhard Marx and others such as Cardinal Wilfrid Napier of Durban standing firm against any change.

The theme of the second Synod session which was held in October 2015 was "The Vocation and Mission of the Family in the Church and in the Contemporary World". The preparatory document was the Relatio Synodi, which summarised the 2014 Synod. It has three sections: Listening: the context and challenges of the family; Looking at Christ: the Gospel of the family; and Confronting the situation: pastoral perspectives.

The first section discusses the socio-cultural context including "a greater freedom of expression and a better recognition of the rights of women and children, at least in some

Pope Francis, Evangelii Gaudium. Nairobi: Paulines Publications Africa, 2013.

See Clague, "Catholic Families", which describes the results of these surveys in 12 countries, including Uganda, 993-1003. 
parts of the world" (\#4). ${ }^{77}$ Some of the problems which are highlighted are individualism, loneliness, "the difficulty of raising children, in a hesitancy to welcome new life and in considering the presence of older persons as a burden" (\#4). Other problems affecting marriage are polygamy as African bishops observed, "marriage in stages", arranged marriages and cohabitation, children born outside of wedlock, the increasing rate of divorce, absent fathers, domestic violence and the sexual exploitation of children (\#7). In the midst of all of these problems the Church "is conscious of the need to offer a word of truth and hope" (\#10), based on Christ.

Section two is a sustained reflection on Christ's teachings and interpretation of family life (\#13). Marriage and the family "have been redeemed by Christ" (\#15) and through the Church the family receives "the grace necessary to witness to the love of God and to live the life of communion" (\#15). A brief survey of the Church's teachings on marriage beginning with Gaudium et Spes follows.

The third section addresses marriage preparation, assistance to couples in the early years of marriage, those married civilly or living together, the separated and the divorced and remarried. It is evident that there was frank discussion at the Synod. For example, in the situation of annulments, some bishops wanted to simplify the process while others opposed this (\#47). A very contentious issue is the possibility of allowing divorced and remarried persons to receive the Eucharist. Some bishops insisted on maintaining the present discipline which forbids this while others "proposed a more individualised approach, permitting access in certain situations and with certain well-defined conditions, primarily in irreversible situations and those involving moral obligations towards children who would have to endure unjust suffering" (\#51).

The teaching of Humanae Vitae is affirmed, but very briefly. The same sections (\#5657) commend families who raise disabled children and affirm adoption and foster parenting.

As October 2015 neared bishops and priests in England and Poland insisted that there be no change in Church discipline in these issues. But Pope Francis also emphasised mercy and said in Evangelium Gaudium that "The Eucharist, although it is the fullness of sacramental life, is not a prize for the perfect but a powerful medicine and nourishment for the weak" (EG 47). He announced a Jubilee Year of Mercy from 8 December 2015 to 20 November 2016.

\section{Amoris Laetitia - The Joy of Love}

Pope Francis wrote Amoris Laetitia - 'The Joy of Love' after the second Synod. It reflects both his own theology of marriage and the family and some of the concerns of the Synods. The first chapter addresses the family unit. Note that the Pope speaks of "you and your wife" $(A L 9)^{78}$ rather than husband and wife. Other chapters discuss challenges of family life, the vocation of the family in reference to Jesus, love in marriage based on 1 Corinthians 13, love made fruitful with children, pastoral perspectives, the better education of children, pastoral discernment challenges and the spirituality of marriage and the family.

The document has a distinct pastoral tone. In discussing the challenges to family life the Pope realises that a new approach is needed:

77 Lineamenta - "The Vocation and Mission of the Family in the Church and Contemporary World." http://www.vatican.va/roman_curia/synod/documents/rc_synod_doc_20141209_lineamenta-xiv-assembly_en.html Accessed 10 November 2016.

78 Pope Francis 2016. The Joy of Love. Nairobi: Paulines Publications Africa. 
We have long thought that simply by stressing doctrinal bioethical and moral issues without encouraging openness to grace, we were providing sufficient support to families, strengthening the marriage bond and giving meaning to married life... We also find it hard to make room for the consciences of the faithful... We have been called to form consciences, not to replace them ( $A L$ 37).

The 2014 Synod stressed that the theology of the sacrament of matrimony is rooted in the sacrament of baptism and $A L$ includes this in its discussion of the sacrament $(A L 73)$.

For Christians, "the sacrament of marriage is not a social convention ... the sacrament is a gift given for the sanctification and salvation of the spouses" ( $A L 72)$. Marriage is a vocation and thus "the decision to marry and to have a family ought to be fruit of a process of vocational discernment” ( $A L$ 72).

The pastoral perspective is evident throughout the document. For example, it states (based on Synod 2015) that:

Therefore, while clearly stating the Church's teaching, pastors are to avoid judgements that do not take into account the complexity of various situations, and they are to be attentive, by necessity, to how people experience and endure distress because of their condition (AL 79).

This is especially clear in chapter 8 "Accompanying, Discerning and Integrating Weakness". Pope Francis emphasises the gradual nature of accompanying people who are not yet ready for the sacrament of marriage such as couples who are living together. He recognises that people live in civil marriage or cohabitation because of "cultural or contingent situations" and that "respect can also be shown for those signs of love which in some way reflect God's own love" (AL 294).

He discusses various kinds of marital situations involving a second marriage where the partners cannot separate, especially for the good of the children. Others include the abandonment of the spouse or a recent divorce. Synod 2015 recognised that "the baptised who are divorced and civilly remarried need to be more fully integrated into Christian communities in the variety of ways possible" ( $A L$ 299). The emphasis is on "a process of accompaniment and discernment" which "guides the faithful to an awareness of their situation before God" ( $A L$ 300). This discernment in the internal forum must be guided by "humility, discretion and love for the Church and her teaching, in a sincere search for God's will and a desire to make a more perfect response to it" (AL 300). ${ }^{79}$

Amoris Laetitia is a rich document on Christian marriage in the $21^{\text {st }}$ century. As will be discussed in the next section, since no woman was able to vote either in Synod 2014 or Synod 2015, there is no way to measure the influence of women in the small working groups on the two Synod documents.

\section{Women at the Two Synod Sessions}

Women participated in both Synod sessions in small numbers but since the Catholic Church continues to refuse to ordain women, all decisions were made by bishops and a few heads of male religious orders. In 2014 there were 192 men who voted; fourteen married couples were observers. In total there were 25 women including one religious sister, Margaret Muldoon of Ireland. Pope Francis appointed four male theologians to advise the bishops. ${ }^{80}$ 
There are many women theologians who have written about marriage and the family, such as Margaret Farley ${ }^{81}$ and Lisa Sowle Cahill ${ }^{82}$ and yet no woman was chosen.

In 2015 there were 17 married couples and in total 32 women attended, including three religious sisters and twelve other laywomen. Ten heads of male religious congregations were appointed and they were willing to give five of their number to women heads. Three women were appointed, but of course they could not vote. One of the men, Brother Herve Janson, superior general of the Little Brothers of Jesus, is not ordained, but as a man, was a voting member. This showed that being a man in Church decision making is more important than ordination. He considered giving up his vote in solidarity with women religious. ${ }^{83}$ There was much comment in the Catholic press about the fact that a synod discussing marriage and family included no women as decision makers.

Lucetta Scaraffia, an Italian historian, commented: “The absence of women's perspectives at times of reflection on these issues is not only an act of disdain towards women who make up more than half of religious and believers, it is also an impoverishment of Catholic life." 84 Catherine Cavanaugh asks: "How does it affect the family to be told that only men can be the imago Christi... And what is it like to have all the decisions at the upper echelons of the church made by men?" 85

Abbot Jeremias Schröder, who attended the Synod, had hoped that more women religious would have been invited. He said that "There is a small recognition that women religious must be present... I had hoped that those nuns, who are involved in so many apostolates of the family, would be a much greater presence than it is currently." 86 Some women who attended the 2015 session, said that they "were encouraged that their views were not only respected but included in the discussions taking place." 87

The Final Report of the Synod refers to women in two sections. Section 7 mentions polygamy and 'arranged marriages' which impact women as "cultural and religious contexts (which) pose particular challenges." 88 Section 8 recognises that "The dignity of women still needs to be defended and promoted. In fact, in many places today, simply being a woman is a source of discrimination and the gift of motherhood is often penalised rather than esteemed." 89 This section also mentions violence against women.

We can only imagine what more might have been said if many more women attended the Synod as full voting members.

One of her most important writings is Just Love: A Framework for Christian Social Ethics. New York and London: 2006.

Among her many writings see Sex, Gender and Christian Ethics. Cambridge: Cambridge University Press, 1996.

75 James Martin, America online: http://americamagazine.org/content/all-things/where-were-voting-women-synod-0. Accessed 2 December 2015.

Quoted in Joshua J McElwee, “Catholic women sharply call for synod to be open to women's participation, voices". National Catholic Reporter, September 17, 2015. http://ncronline.org/news/people/catholic-womensharply-call-synod-open-womens-participation-voices. Accessed 30 November 2015.

85 Quoted in Joshua J McElwee, "Catholic women sharply call for synod to be open to women's participation, voices”. National Catholic Reporter, September 17, 2015. http://ncronline.org/news/people/catholic-womensharply-call-synod-open-womens-participation-voices. Accessed 30 November 2015.

88 Final Report of the Extraordinary Synod on the Family. http://www.dioceseofshrewsbury.org/news/latestnews/vatican-publishes-final-report-extraordinary-synod-family-text-full. Accessed 30 November 2015. 


\section{Africa}

And what of Africa? Before and during the Synod sessions various African bishops such as Cardinal Robert Sarah of Guinea insisted that the issues of the West, such as the admission of divorced and remarried persons to the Eucharist, were not African concerns. Since Vatican II African bishops have been calling attention to the problems caused by polygamy. Traditionally it was used "to protect women and to assure stability in marriages where childlessness might have led to adultery" $"$ but today it is often a sign of male status and power. African feminist theologians challenge it on many grounds. Anne NasimuyuWasike of Kenya argues that "even in traditional rationales for polygyny show it to be an arrangement for the sake of men and harmful to women." 91 She asserts that women in polygynous marriages project their dislike not on their husbands or the institution as such but on the co-wives: "The tongue of co-wives is bitter.",92

In South Africa the issue of lobola - the exchange of cows or 'cash cows' to the bride's family - was originally designed to bring the two families together. But in a rapidly urbanising country, young men (and their families) often do not have the money for lobola. Thus the young couple cannot marry and so live together, giving neither the wife nor the children legal protection. Christians cannot marry in church unless the traditional ceremonies have been held, including payment of lobola.

The HIV and AIDS pandemic has also profoundly affected family life. The death of the parents, especially before ARVS became widely available, left the children to the care of grandparents, usually the grandmother. In other situations, children as young as 10 took over the work of raising their siblings, usually with the assistance of friends and neighbours. The freedom that African culture often gives to men to have sexual partners outside of marriage has also placed African women at risk. Traditionally, "once married, women's bodies belong to their husbands" but "husbands' bodies can be shared with other women." 93

The work of many members of the Circle of Concerned African Women Theologians such as Beverly Haddad, Musimbli RA Kanyoro, Fulata Moyo, Mercy Oduyoye, Isabel Apawo Phiri and others brings women's voices to the conversations about African family life and marriage. Farley notes that while they "affirm the African communitarian character of sex, marriage and family, they believe it can be sustained only in ways that do not threaten the inherent dignity of women or ignore women's need for some degree of economic and social control over their own lives."94

\section{Feminist Voices: A Critique}

While various church documents since Vatican II mention the situation of women in marriage and the family, the reality is that these documents are written by celibate men, whose experience of family life is that of their family of origin many decades ago and observation of the family life of their married siblings. The voices of women are only background voices even though since Vatican II Catholic women on all continents are theologians and have written widely on all theological topics, including marriage and the

\footnotetext{
Farley, Just Love, 83.

Cited in Farley, 87.

Quoted in Farley, 87.

Farley, 85.

Farley, 84.
} 
family. Thus women's experience, a foundation in doing feminist theology, ${ }^{95}$ is lacking. In 2014 Pope Francis named five women to the International Theological Commission which has 30 members, the largest number to date. They are from Australia, Canada, Germany, Slovenia-Russia and Germany - note the absence of Africa and Asia.

Some women have energetically supported John Paul II's Theology of the Body even though it is based on the physical essentialism of Urs von Balthasar. ${ }^{96}$ Janet E Smith of the United States is an especially prominent defender of the pope's views. ${ }^{97}$

Two feminist ethicists provide important insights on marriage and the family. Margaret Farley describes the criteria which make the framework of marriage just: "free choice, mutuality, equality, commitment, fruitfulness and a responsibility for the wider world." 98 She critiques the 'total gift' language of the Church documents, querying if "it is even possible for one person to give him or herself totally to another." 99 This language is especially dangerous for women who are socialised to serve others.

Farley relates her framework for justice in marriage to the scourge of domestic violence which is an issue of power. She notes how "violence can rise from a sense of powerlessness effected by religiously inspired but unrealistic expectations placed upon persons in family roles." ${ }^{100}$ Some seem to tolerate domestic violence since it is "contained' within the family.

Lisa Sowle Cahill, a married theologian with adult children, also critiques the Church's teaching on marital experience and the language of 'total gift' in marriage. She asks, "On what basis is it affirmed that marital experience requires procreation as the completion of conjugal love (especially if tied to each sex act)?"101 When persons do give themselves totally it is seldom in one act, but in many such as a life of faithful and committed love. She asks: "Would we subject the self-offering of the priest in the Eucharist to such a standard (under pain of mortal sin), even though the priest is supposedly standing in for Christ himself?" 102

Discussing male and female experiences of marriage, she describes marriage as a "safe haven" for men, "the counterbalancing sublimation of sexual gratification into socially constructive human relationships," but for women "marriage and family are dangerous, at least as traditionally practiced." 103 They seek "a mutually responsible and intimate human relationship in sex."104

In Familiaris Consortio (1981) Pope John Paul II relates discernment to the sense of faith, of "the experience and expertise of lay people in discerning its response to the

See among many resources Serene Jones, “'Women’s Experience’ Between a Rock and a Hard Place: Feminist, Womanist and Mujerista Theologies in North America.” Religious Studies Review 21:3, 1995:171-179. Rosemary Radford Ruether places experience at the centre of feminist theology: "Human experience is the starting point and the ending point of the hermeneutical circle. Codified tradition both reaches back to roots in experience and is constantly renewed or discarded through the test of experience. 'Experience' includes experience of the divine, experience of oneself, and experience of the community and the world, in an interacting dialectic." Sexism and God-Talk. Boston: Beacon Press, 1983, 1993:12).

96 See Rakoczy, "Mixed Messages", 162-164.

97 She edited Why Humanae Vitae was Right: A Reader. San Francisco: Ignatius Press, 1993.

98 Farley, Just Love, 265.

99 Farley, 266.

100 Farley, 267.

101 Lisa Sowle Cahill, Sex, Gender and Christian Ethics. Cambridge: Cambridge University Press, 1996:203.

102 Cahill, Sex, Gender and Christian Ethics, 203.

103 Cahill, 198.

104 Cahill, 199. 
pastoral challenges facing families." 105 The surveys before the Synod sessions showed a wide disconnect between Church teaching and its reception by the lay faithful, so much so that Clague says that they "appear to inhabit different Catholic worlds". ${ }^{106}$ The institutional Church continues to condemn abortion, contraception, and sexual activity outside of marriage. Where is the listening Church, a Church that takes the experience of married couples, especially of women, seriously?

\section{Conclusion}

The Synod discussions and Amoris Laetitia are crucial but they are not the last step. New structures need to be constructed so that the voices of the lay faithful on every continent help to shape the Church's teachings on marriage and the family, and on every important issue of ecclesial life.

Marriage is a lay vocation and the development of theologies of marriage is a special responsibility of married couples. This call is rooted in baptism and as the US bishops wrote: "It is characteristic that lay men and women hear the call to holiness in the very web of their existence ... the complex decisions and conflicting values they must struggle with, the richness and dignity of sexual relationships..."107. Since Vatican II many lay women and men have become theologians, including specialising in moral theology and the theology of marriage. Synods and other church bodies which discuss marriage without a substantial lay voice cannot reflect lay experience. And thus the Church's theology of marriage remains impoverished.

Thus it is the responsibility of the People of God, all of whom are guided by the Spirit, to discern together the direction the Spirit of God is leading the Church, so that "life to the full" (John 10:10) flourishes in families and communities. 